\title{
Historical consciousness and existential awareness in Karl Barth's hermeneutics
}

\author{
G M M Pelser \& Andries G van Aarde ${ }^{1}$ \\ Faculty of Theology \\ University of Pretoria
}

\begin{abstract}
Karl Barth's hermeneutic legacy prolonged Western Christian tradition, especially influenced by Hegelian philosophy of history. This led to Barth's "theological exegesis" instead of a historic-critical exegesis. In a preceding article Barth's understanding of the notion "hermeneutic circle" is discussed against the background of the Enlightenment and its counter-movement in Romanticism. In this article Barth's attitude to the place and role of historical criticism is explained in light of his dialectic distinction between "scientific" and "practical" interpretation. The article aims to show that Barth, with his dialectics, continues Schleiermacher's realism. In conclusion, the positivistic traits in the Barth legacy are raised once again, in order to open the door to Jürgen Habermas and other deconstructionist thinkers of the postmodern era in hermeneutics.
\end{abstract}

\section{INTRODUCTION - A REAWAKENING OF HISTORICAL CONSCIENCE}

As a result of the influence of the Aufklärung it is clear that a trajectory was developing which would later be called dialectical theology, in contradistinction

\footnotetext{
${ }^{1}$ Gert M M Pelser and Andries G van Aarde are retired professors who previously lectured in the Department of New Testament Studies, Faculty of Theology, University of Pretoria. This essay is a following-up article on the historical-hermeneutical prelude to the legacy of Karl Barth (see Pelser \& Van Aarde 2007:1347-1375).
} 
to liberal theology. Not only did the philosophers $\mathrm{Hegel}^{2}$ and $\mathrm{Kant}^{3}$ play important roles in this development, but so too Dilthey ${ }^{4}$ and Heidegger. ${ }^{5}$ Dilthey's hermeneutic reflections ${ }^{6}$ covered a much wider perspective than those of Schleiermacher. It had as its starting point in his resistance to the empirical approach to history, which intended to study historical phenomena in the same way as the natural scientist did with natural phenomena. This approach regards history merely as cause and effect, and does not have an eye for the uniqueness of historical phenomena. In contrast to this, Dilthey envisaged a science of history which would take uniqueness into account; and he wanted to accomplish it with a criticism of historical reason. Dilthey states that historical phenomena and the human manner of being are not determined by laws but are the uncompleted, unpredictable process of becoming over time. He calls this manner of being life, but in the sense of a spiritual creative urge and creative force, not of a biological process. It concerns the life experiences (Erlebnisse) through which people decide for themselves what the meaning of their existence is.

Life experiences constantly press for expression in external forms. They are products of culture in contradistinction to processes of nature. As products of culture, they are the bearers of meaning by means of which life interprets itself. And owing to their durability, they are accessible not only to contemporaries but also to people of later times. As bearers of the meaning of life, they have a communicative function: they want something to be understood. The pursuit of knowledge in respect of similar phenomena should be aimed at the quality of their meaning and the manner of knowing is that of understanding. Therefore, according to Dilthey, the manner of knowing regarding historical phenomena is that of understanding in contrast to explaining which is the manner of knowing

\footnotetext{
${ }^{2}$ See G W F Hegel [1969], Hegel's science of logic; [1986a], Vorlesungen über die Geschichte der Philosophie, II. Werke in 20 Bänden, Werke 19; [1986b], Vorlesungen über die Geschichte der Philosophie, III. Werke in 20 Bänden, Werke 20. Cf also inter alia D Henrich ([1967] 1971), Hegel im Kontext; H Küng ([1970] 1989), Menschwerdung Gottes: Eine Einführung in Hegels theologisches Denken als Prolegomena zu einer künftigen Christologie; W Jaeschke (1986), Die Vernunft in der Religion: Studien zur Grundlegung der Religionsphilosophie Hegels; J Ringleben (1994), Hegels neue Philosophie des Lebens von der Bibel aus, in Ziegert, R (Hrsg), Die Zukunft des Schriftprinzips, 75-92.

${ }^{3}$ See, esp, I Kant ([1793] 1977), Die Religion innerhalb der Grenzen der bloßen Vernunft, in Die Metaphysik der Sitten: Werkausgabe VIII, hrsg von W Weischedel, 645-879 (cf Kant [1793] 1914).

${ }^{4}$ See inter alia W Dilthey [1960], Zur Preussischen Geschicte, in Wilhelm Diltheys Gesammelte Schriften, Band 12; [1972], Leben Schleiermachers, hrsg von M Redeker, in Wilhelm Diltheys Gesammelte Schriften, Band 13.

${ }^{5}$ See inter alia M Heidegger [1962] 1972. Being and time; (1971), Poetry, language, thought.

${ }^{6}$ See inter alia H A Hodges (1944), Wilhelm Dilthey; (1952), The philosophy of Wilhelm Dilthey.
} 
regarding natural phenomena. Natural phenomena can be deduced; but in contrast to this, experiences of meaning occur in a non-deducible manner in time.

In his hermeneutics Dilthey also asks how understanding is possible and how it can lead to scientific knowledge. To him the possibility that understanding can be a problem relates to the nature of historical consciousness. On the one hand, historical consciousness is characterised by an involvement in historical tradition, by what addresses us from the past, and on the other hand, by an experience of strangeness. In other words, we do not accept everything as obvious. The strangeness pertains to the distance in time, and due to this strangeness, a deliberate and conscious attempt to understand is needed. This requires a step back to the time and a reconstruction of the circumstances and spiritual milieu of the time in which the cultural product originated.

Authentic understanding is the Nach-erleben (after-experience) of an original Erlebnis (life experience). But it is always simply a Nach-erleben and is never identical to the original experience. Those who "understand" can indeed place themselves in the original situation, but they never detach themselves from their own situation, so that they always understand from the perspective of the latter. Only in this way can the strangeness be overcome and will understanding not be a mere repetition of the original. That understanding is possible, is situated in the time-spanning universality of life's movement. It is the same principle of life which found expression then, and now makes a reexperience possible. Historical knowledge is therefore possible thanks to the similarity of knower and known as revelations of the same maxim of life.

Dilthey defined interpretation as an artful (kunstmäßige) understanding of permanently fixed expressions of life, and hermeneutics as artistic theory (Kunstlehre) of the understanding of written, fixed expressions of knowledge. Like Schleiermacher, he also used the divinatory as point of departure. He believed the divinatory to be based on the genious of the interpreter, a talent which rarely occurs. Since interpretation is also practised by the less talented and has to be learned by them, it is essential that the art of gifted interpreters as laid down in their method, should be retained in the rules of interpretation. But gifted interpreters, the actual interpreters, are high above the rules of interpretation. They succeed in re-experiencing alien spiritual conditions. Through good fortune they succeed in understanding the singular, the historically once-only, which they have to elevate to objectivity. With great luck they can (vermag) experience a repeated enjoyment of the magical power (Zauber) of bygone cultures. The divinatory therefore consists of post-feeling, post-understanding, post-enjoyment, in the sense of re-experiencing life's expressions. 
Dilthey claims that this is why understanding means to recognise from signs observable through the senses something psychic, of which these signs are invariably the expression. The objectivization of life, which as spirit expresses itself primarily in texts, has to be translated back by means of understanding into the full, total liveliness of the interpreter. Historicity (Geschichtlichkeit) takes place in two phases: life creates objectivizations of itself; the objectivizations are translated back into full, total liveliness.

As the winning points of Dilthey's approach, it is pointed out that he tried to make historical consciousness comprehensible in terms of hermeneutic experience. This cuts both ways: on the one hand, he tried to show the way in which the so-called crisis of historism could be overcome. He showed, namely, that history is not about bygone states of affairs which have no validity or lifeorienting relevance for people in the present. This also entails that human beings cannot approach the expressions of meaning in history as uninvolved observers who merely establish and explain facts, but only as people who are addressed by history and are opening themselves to the acknowledgement and deciphering of a cognitive claim to meaning. On the other hand, he showed that the problem of understanding not only concerns interpersonal communication through the medium of language, and that the attempt to understand is not only aimed at avoiding misunderstanding in the communication process. What it is about, is that "readers" as agents of interpretation are addressed inwardly in their historicity through their cultural heritage, and that they must and can decipher this claim with a view to deepening and enriching their own existence in the present. Another winning point of Dilthey's approach is his insight that understanding occurs in the context of history. This means that it is always relative to the situation in which interpreters find themselves and that that which is to be understood, can only be authentically understood when the "understander" is addressed by it in her or his situation. The implication of this insight is that interpretation can never be final but invariably has to be undertaken anew in every new situation.

The misgivings include the fact that Dilthey sees the attempt to understand primarily as the bridging of the time-distance between past and present. He, therefore, remains trapped in Schleiermacher's conception of understanding as a reproduction of an original production. The question is whether the time-distance can or should be bridged. If the time-boundedness of the act of interpretation is taken really seriously, bridging the time-distance must be regarded as fundamentally impossible. The understanding subject can never place himself or herself back in time to be truly "contemporaneous" with the original situation of what is attempted to be made intelligible. What was experienced in the past, can only be understood as it addresses the potential 
"understander" in the "present". To understand the same, it must be understood differently. The distance in time should rather be seen as a positive prerequisite for understanding because it makes one aware of the strangeness.

Interpretation is not a reproduction of the original production. It is rather the re-capturing of a meaning which was once upon a time expressed, in order to be actualised in the present. Authentic understanding is not only interpretability, but also the applicability of expressed meaning. Application is not a coincidental and non-essential element of the interpretation process, but belongs to the essential structure of interpretation, due precisely to the futuristic dimension of all meaning.

\section{A RECONNOTATION OF THE "HERMENEUTICAL CIRCLE"'}

The transition from Schleiermacher to the twentieth-century theologians Barth and Bultmann goes hand in hand with the continuum in philosophical thinking between Kant, Dilthey, and especially Heidegger. ${ }^{7}$ For Heidegger the hermeneutic problem is primarily an ontological theme. For him it is about the philosophical question relating to the reality of actual phenomena, that is to say, the being of the beings. It is about the question of how human beings can understand and interpret what is made plain by all real phenomena.

Moreover, saying that interpretation or understanding is an ontological theme means that interpretation itself is a way in which reality appears. Interpretation is namely constitutive for human beings' manner of existance. People show their real reality as being therein that they interact knowingly or interpretatively with reality, their own reality as well. They appear to themselves fundamentally as "readers" but also to the whole of the reality that gives something to be understood to them. What actual phenomena make plain to them, is their "reality" or "being". And so people also make their own reality plain to themselves.

Heidegger's hermeneutics is an attempt to shed light on the conditions for the possibility of understanding as a manner of being in human existence. $\mathrm{He}$ uses the term Dasein to indicate human existence, a term which usually means "being there" but which he reserves for human existence. Dasein wellnigh means "human being", because it characterises the human mode of existence in contrast to that of worldly objects such as stones, chairs, and so forth. As

\footnotetext{
${ }^{7}$ Cf inter alia F Hohmeier (1964), Das Schriftverständnis in der Theologie Rudolf Bultmanns; W Schmithals (1967), Die Theologie Rudolf Bultmanns: Eine Einführung; W Stegemann (1978), Der Denkweg Rudolf Bultmanns: Darstellung der Entwicklung und der Grundlagen seiner Theologie; J Painter (1987), Theology as hermeneutics: Rudolf Bultmann's interpretation of Jesus; M Evang (1988), Rudolf Bultmann in seiner Frühzeit.
} 
Dasein, a human being may not even be seen by psychology as an "object of study". Therefore, to Heidegger the use of this concept concerns people in their "subjectivity", the "place" or "space" in which the being is present. But this presence is not static. It happens. It is an event in which being happens, in which it arrives at a there.

This event has two sides. On the one side, Dasein is the event in which the being shows or reveals itself. On the other side, Dasein is also the event of the unfolding of the being-in-the-world. It is the indication of meaning or interpretation of the being. It is the act in which the being which makes itself plain, is indeed also understood. Furthermore, the being which makes itself plain in the being-in-the-world (= Dasein), is first and foremost itself the being of the being-in-the-world. That is why the understanding of this being is before all else a self-understanding. As self-understanding, the being-there is the event of selfactualisation, in other words the putting into effect of the being's own reality.

The event of understanding is temporary in the sense that it cannot be completed. And there are two aspects that are apparent from this impermanence. Firstly, the understanding of the being has the character of design: the creative giving of form to and projection of the possibility of being which is not yet being, but could be. The being is therefore primarily understood as a "could-be" (Seinkönnen). The term "design" emphasises the non-derivable historicity of the event of understanding. Understanding is not the discovery of already-given talents or natural potentialities. It is the designing of possibilities for self-actualisation which only originate in the design thereof. As design, understanding takes place in a free, indeterminate decision. It is a contingent and non-derivable act. In the free design, people allow their own being to accrue to themselves as a possible being. In this way a future dimension is created, and understanding as design exceeds that which is given in the present as already actualised, as factuality. The future is opened and the being makes itself subsequently plain. The future is therefore an essential condition for the being to achieve actualisation, for the being to become meaningful and to reveal the sense of being. For this reason, the being becoming meaningful and the revelation of its sense, can in principle not be completed.

Secondly, the free design of possibilities takes place from a field of realised possibilities: people's past as having been, over against their past as irrecoverable pastness. This "having been" is the factual situation into which they are cast, and in which they landed without their own doing. People are interested in their "having been", their history, owing to the already interpreted sense of being handed down to them (by tradition). Understanding as casted design is inextricably linked to the "having been" of people, and as casted design it is future-oriented. Understanding people are namely interested in their 
origins owing to their concern about their future. Therefore, understanding is the design of future possibilities based on people's factual situation.

Before Heidegger, the concept "hermeneutic circle" was understood as the movement from the part to the whole of the text, and vice versa. But for Heidegger it was a cycle of Vorverständnis and Verstehen. In terms of this, the conviction is held that understanding never begins at a zero point. Being able to understand presupposes that understanding already occurred. This is only possible from a given horizon of meaning, which Heidegger calls Vorverständnis. However, the given Vorverständnis is exceeded and also changed through understanding. The "Vorverständnis" conditions the interpretation but does not determine it.

Vorverständnis is a social phenomenon, because it concerns a body of understanding which one shares with other people. This shared world is constituted by an already interpreted sense of being or already realised possibilities of being in respect of which a community of people have reached consensus. This consensus comes into being through language. People speak the same language about the sense of being and therefore Vorverständnis is at the same time also Einverständnis.

Understanding implies self-interestedness, the decision a single person makes in his or her striving for self-actualisation. This decision for new possibilities of being is on the one hand determined by the communal horizon of meaning, and on the other it constantly presses toward sharing with the fellow human being. And because Dasein is always also Mitsein, the sense of being that is articulated in interpretation is not a sense of being for-me-only, but it gains its hallmark of authenticity only when it becomes a shared sense of being. The medium of this sharing is inter-human discourse. It envisages a new Einverständnis which in turn functions as Vorverständnis for a new Verstehen.

In conclusion, Heidegger states that language is the dwelling of the being. As the dwelling of the being, language is living speech as it functions in the continuing inter-human discourse. The continuing inter-human discourse, with all its tension and mutual conflict, is a structural precondition for the sense of being's becoming meaningful and being revealed.

\section{A REINFORCING OF EXISTENTIAL INTERPRETATION}

The Karl Barth legacy cannot be understood unless it is also weighed against the background of Rudolf Bultmann's (1884-1976) hermeneutic programme. There is no doubt that in many respects, Bultmann's hermeneutics had a profound and, for many, an unsettling effect on the theology and the hermeneutic thinking of the twentieth century. Bultmann based his 
hermeneutics, although also with certain deviations, on the existential philosophy of Heidegger.

As we saw above, Heidegger focused on the phenomenon of human existence or being-in-the-world (Dasein) and he defined understanding as the ability to gain a comprehension of your own possibilities of existence in the context of the life-world in which you exist. However, this understanding not only concerns the situation in which people find themselves at a specific moment but also their possibilities of existence in the future. In the footsteps of Heidegger's theory of understanding, Bultmann posits that it is essential for exegetes to consider Biblical concepts critically if they want to introduce the Bible itself as a telling power in the present, in the human existence of the here and now.

Similar to Barth, Bultmann also believes that conquering historism in the interpretation of the Scriptures is of cardinal importance in hermeneutics. As mentioned above, especially seen as a result of Dilthey's insights, Bultmann also held the conviction that historical investigation does not, as is the opinion of historism, consist of the presuppostionless rendering (reconstruction) of the past, but that consists of an epistemological confrontation with history which is attuned to a decision.

The important question for Bultmann is: how can the texts handed down through the ages, in view of their historicity (their ties to the historical situation in which they came into being) address people existentially today? Since the Bible is a historical document, the historical question for Bultmann is an inescapable assumption for the investigation of the texts. Exegesis, as the interpretation of these texts, is a historical science and this investigation can only be done objectively, in other words in a presuppositionless manner. Since the results of historical research can never be regarded as concluded, however, historical research cannot yield results that have absolute validity. As bare historical facts, the Biblical data are subject to historical investigation and are not generally valid. But as addresses to human beings, it is different.

Bultmann gives full recognition to historical-critical investigation as modern scientific concept, because he regards historicity (Geschichtlichkeit) as something completely different. He namely distinguishes between what he refers to by the concepts historisch and geschichtlich (concepts which are, by virtue of their semantic particularity in German, "untranslatable"). He understands historisch as the ordinary historical factuality of an event, whereas geschichtlich refers to the existential consequences of such an event or to existence as such. In view of this distinction, Bultmann had no problem with the Bible's being subjected to the sharpest and most penetrating historical criticism, because the matter concerned in the texts is not that which can be verified or falsified by means of historical investigation, but what these texts say about 
human existence, independently of verification or falsification. The matter which it is really about is therefore not the historische but the geschichtliche.

Human existence is geschichtlich and the geschicktlichkeit of the exegete/reader only becomes actualised in the posing of questions which concerns him or her and his or her existential involvement therein. In respect of Biblical texts, this means that the genuine historical question is determined by the question of the understanding one's own existence on the basis of the understanding of existence expressed in the texts. The believing reader of the Bible is confrinted by the "non-objective subject matter" of the Biblical text and through this kerygmatic event the text demands unconditional obligation. However, it is precisely the non-objectiveness of the Biblical subject matter that guarantees such an unconditional demand for obedience, whereas every objective pronouncement always remains dubious owing to the historicity (and therefore falsifiability) of all traditions.

When the phenomena of history are interpreted as possibilities for understanding one's own existence, faith remains free of bondage to the worldview of a particular time, and in particular that of Biblical times. This means that the closedness of the modern worldview is not breached. It furthermore implies that faith is not exchanged for a subjection of people to an old (and obsolete) worldview and a coerced sacrificium intellectus. The radical nonobjectiveness of the matter that the Bible is concerned with, rises above historical relativism; it can therefore not be endangered by the results of historical investigation, which are relative because they can always be amended. Consequently, such a "cultural-criticism" and "hermeneutics of suspicion" makes it impossible that faith can be understood as a static entity. Because the Bible's claim for faithful obedience happens by addressing the believing reader in a non-objectifying manner, the kerygma does not intend to speak about objects but about existence. The listeners to the Biblical texts are addressed existentially in their Geschichtlichkeit and called upon to make a decision about faith, whereas the texts as historical phenomena are limitlessly subject to historical criticism. As mentioned above, it does not therefore bother Bultmann that the Bible is investigated historical-critically, because he understands something entirely different by geschichtlich than the matters of interest to historical investigation.

Bultmann bases the fact that he regards the Biblical addresses as nonobjective on the conviction that theology cannot make objective pronouncements about the Transcendental. For this reason, an objective statement cannot be made about God, because God would then be reduced to a world-thing. Pronouncements about God are only possible as anthropological 
pronouncements, in other words as pronouncements about people and their existence. The Biblical texts should therefore be interpreted according to human beings' self-understanding (Selbstverständnis). The texts themselves are witnesses of such self-understandings. Stated differently, the question should be asked about the human Existenzverständnis that is expressed in the texts. This is the essence of existential interpretation, which can also be called anthropological interpretation, because it always concerns anthropological pronouncements. This opinion of Bultmann creates the impression that God does not exist outside a faith-relationship. He however denies such a conclusion.

Although Bultmann, as stated above, leaned strongly towards existential philosophy, his theology does not become wrapped up in existential philosophy. It differs from existential philosophy in that the new self-understanding cannot be actualised by human beings themselves, but only through the mercy of God which comes from outside, namely by means of the addressing Word, the kerygma. The mercy of God is experienced in the word that is proclaimed right now, and the faith of the hearer is nothing else than the answer to the appealing word. The call of God occurs by means of a historical event, in the person of the human being, Jesus Christ who is proclaimed to us. It remains the mythological rest, the fact that God approaches us in this historical man, Jesus of Nazareth. With this, Bultmann holds on to the extra nos of the salvation events. But the kerygmatic addresses can only be heard existentially. As they do not have an objective nature, they cannot serve as proof for objective thinking. Conversely, the kerygma is not subject to historical criticism either, as historical facts are. The kerygma can only be adopted in faith and obedience, or be rejected.

The person and history of Jesus, according to Bultmann, have no meaning for the proclamation of the kerygma. In order to understand that Christ is the redeeming act of God, it is only necessary to proclaim the that of his coming. The that of his coming becomes a historical point without corporeality. Therefore Bultmann believes that the historical Jesus can be excluded from the proclamation. To ask about the historical Jesus behind the kerygma, is not intended to reinforce faith. That Jesus Christ remains the end of history, is remains in the world of time and space a matter which cannot be fathomed. If the objective pronouncements of the Bible are interpreted existentially as they ought to be, the worldview of the modern person is nowhere breached by incredible "wonders". The radical de-objectification of the kerygmatic addresses 
by means of existential interpretation is breached at only one point: it remains to have a bearing on the act of God in the that of the coming of Jesus. ${ }^{8}$

To Bultmann, the following are of basic importance for understanding a text:

- Understanding proceeds from the supposition that the text will be questioned about the matter it is concerned with.

- A further supposition of every understanding interpretation is the preceding (already existing) relationship to life (Lebensverhältnis) that the exegete/reader has with the matter which is directly or indirectly put into words in the text.

- This life context of the matter is the basis for the pre-understanding (Vorverständnis) of the exegete/reader. This means that every interpretation is determined by the with-what-purpose (Woraufhin) of the question. The interest in the matter motivates the interpretation. Every question to the text is therefore always some or other oriented question.

\footnotetext{
${ }^{8}$ Bultmann's view on the theological relevance of the historical Jesus has often been wrongfully used to validate the view that a quest for the historical Jesus is "impossible". Bultmann was prompted by Albert Schweitzer's finding that exegetes who draft biographies of Jesus often project their own ideologies onto their images of Jesus. Such ideologies include the exegetes' own ideas regarding ethical-religious perfection, goodness, sinlessness, and holiness. These are projected onto the inner being of the person Jesus (cf C R Joy [1948], Introduction: Schweitzer's conception of Jesus, p 23). Bultmann called this "psychological fallacy". One cannot describe another person's mind. Earlier, Martin Kähler (1969), Der sogenannte historische Jesus, p 14, had already pointed out that a biography of Jesus would be impossible since sources did not mention Jesus' psychological disposition. Therefore, Albert Schweitzer reacted against theories about supposed mental disorders in the mind of Jesus. In his doctoral thesis, The psychiatric study of Jesus, which served as the completion of his medical examinations, Schweitzer responded to the work of four "psychopathologists". They claimed to build upon Schweitzer's view that Jesus' activities were those of a "wild" apocalyptic prophet (Schweitzer 1948:46-53; cf also A Schweitzer [1913], Geschichte der Leben-Jesu-Forchung, pp 362-367). Schweitzer's reaction to these "psychopathologists" was similar to his reaction to the "liberal theologians" from the previous century. According to Schweitzer, they constructed a "liberalized, modernized, unreal, never existing Jesus ... to harmonize with [their] own ideals of life and conduct" (Joy 1948:19). In his well-known Jesus book, Bultmann ([1926] 1988) Jesus [Neuausgabe], pp 8-10) agrees that, "psychologically speaking" (psychologisch verständlich), we know virtually nothing of the "life" and "personality" of Jesus. Bultmann's student, Ernst Käsemann also agrees with this. Käsemann ([1954] 1960), Das Problem des historischen Jesus, pp 212-213) puts it as follows: "Bei einem Leben Jesu kann man schlechterdings nicht auf äußere und innere Entwicklung verzichten. Von der letzten wissen wir jedoch gar nichts ...." But, according to Walter Schmithals (1988:149), another Bultmann-student, in the Nachwort to Bultmann's Jesus book, a gross misunderstanding ("ein groteskes Mißverständnis") could arise here. It is misleading to believe that Bultmann (or Schweitzer, for that matter) considered it impossible to carry out a historical investigation of Jesus. Bultmann (1988:13; cf also Painter 1987:102) also says that we know enough of Jesus' message to be able to draw a coherent picture of him. The problem is not that we know too little of the historical Jesus. The question is whether this knowledge is at all relevant for faith. This issue nearly caused the debate between Bultmann and his students (in particular Ernst Käsemann and Joachim Jeremias) to become personal. Fortunately, both Käsemann and Bultmann declared that the matter at hand was more important than persons (see Käsemann [1964] 1969), Blind alleys in the "Jesus of History" controversy, p 36; and Bultmann 1965, Antwort an Ernst Käsemann, p 190). Bultmann notes: "Denn ich bin mit Käsemann ganz darin einig, daß die Sache wichtiger ist als die Personen, und daß der Zusammenhalt einer Gemeinschaft, wie sie zwischen Käsemann und mir bestand und besteht, Spannungen ertragen muß, unter denen das persönliche Verhältnis nicht zu leiden braucht, - Spannungen, deren Diskussion nur zur Klärung der Sache, an der uns gelegen ist, beitragen kann."
} 
The Woraufhin can be identical with the intention of the text, and is then said directly through the text. By contrast, it can also be non-identical, and is then situated indirectly in the text.

- The purpose of the question may be aimed at things which only indirectly concern the intention of the text (e.g. reconstruction of the historical facts, psychological, aesthetic or sociological phenomena). In respect of religious texts, however, the question should be aimed directly at the intention of the text, in other words at the understanding of human existence that is expressed in it.

Historism had the ideal of reconstructing the historical facts without suppositions. Bultmann does not regard this as possible, because the actual, true meaning of historical events are not observable for a neutral, uninvolved observer. Here we can also see the influence of Kant (via Schleiermacher and Dilthey). This view of the "subjective" nature of historicity is often seen as an alternative to the view of Leopold von Rancke (1824) who describes the task of historiography as to establish "wie es eigentlich gewesen ist." ${ }^{\text {"In }}$ other words, the investigator must (try to) reconstruct the historical situation as it really was. Experts on Von Rancke point out today, however, that Von Rancke did not mean the word "eigentlich" as historically real in the positivistic sense of the word, but historically essential. In this regard there is consequently no difference between Von Rancke and Bultmann.

According to Bultmann, texts can only really fulfil their task as historical sources if they are questioned about their understanding of human existence. Perfect objectivity in understanding a text is not possible, however. The investigator is him-/herself part of history and stands to an existential relationship to history. The subjectivist, that is existential, interpretation is the most objective here. Only the question that is brought to the fore through one's own existence, can hear the addresses of the text. However, subjectivity does not mean fantasy and arbitrariness. The existential meeting with the text has no other purpose than to obtain valid, objective results which can then be criticised and about which discussions can be held.

Exegetes/readers cannot eliminate their pre-understanding of the matter, nor should they try to do so. After all, the text is mute without this preunderstanding. However, pre-understanding must be tested critically and this means that in their questioning of the text, they must allow themselves to be questioned by the text. Their pre-understanding or preconceptions must be

\footnotetext{
${ }^{9}$ See Leopold von Rancke's ([1824] 1973), Geschichte der romanische und germanische Völker von 1492 bis 1535, in G C Iggers \& K Von Moltke (eds), Introduction, in The theory and practice of history, xix-xx.
} 
subjected to the correction of the text. The intention of the question to the text, namely to achieve Existenzverständnis, cannot however be questioned. Though there will always be a pre-understanding (Vorverständnis) of the life areas of human existence present to a lesser or greater extent among people, there indeed remauns the question of how something like this can exist with regard to the unknown God. If God, as Bultmann rightly contends, is not a worldly object, not part of the closed framework of human existence, how is a preunderstanding of God possible? In response to this, Bultmann states that it is based on the need everyone has for God. He calls it: Das existentielle Wissen um Gott. This is actually existentielle Wissen um Gott (meaning the interpretation of "Gottes Offenbarung"); is actually in a certain sense an anthropological question; and to Bultmann (see again the influence of Schleiermacher) it is the "Frage nach der Wahrheit der menschlichen Existenz".

For Bultmann there is only one way in which one can question or interpret the texts of the Bible regarding the matter that these texts are about, and that is to interpret them demythologisingly and existentially. As regards demythologising, his programme consists of two parts, namely a historical and a philological. Historically it concerns myth as a history of religion phenomenon which is the product of the worldview and the belief of a bygone era, a phenomenon which should be purged or interpreted by every exegete/reader according to its meaning. ${ }^{10}$

According to Bultmann, it is unquestionable that in the Bible, and therefore also in the New Testament, we are dealing with an old and mythical worldview, for example that the world consists of three storeys, namely heaven, earth and the underworld. Science has proven that this is not so and that modern people can no longer believe it. If modern people were still to cling to this old worldview ("das mythologische Weltbild"), they would have to commit a sacrificium intellectus. The Bible does not want to force this worldview on us, however, and therefore we must ask what is meant by this image. This can be done by demythologising. To distinguish the myth as a phenomenon in the history of religion is to distinguish the mythical manner of speaking about certain matters, such as God and the supernatural. In human language and representations, these things are said about as if God and the supernatural are part of the world. It is mythical speaking which must be interpreted, and in the

\footnotetext{
${ }^{10}$ Before Bultmann, as noted above, D F Strauss in his interpretation of the New Testament studied in all earnestness the mythological character of the testimony of the New Testament. $\mathrm{He}$ found both the rationalist and the conservative methods of interpretation unacceptable, and he put the mythological in their place. He regarded the larger part of the Gospel material as mythical. The tales told about Jesus, especially the miracles, had all been constructed by the earliest church around a particular "idea" about Jesus. When interpreting these reports, therefore, it is not the "shape" in which the idea is cast that is important, but the idea itself that is expressed in it. The interpretation must therefore be aimed at reconstructing this idea. It is mainly ascribed to Strauss that the investigations launched after his time into the historical Jesus, concentrated much more on Jesus' words than on his deeds.
} 
end it is all about the Existenzverständnis of the author(s), that is expressed in these representations. Demythologising envisages nothing else than to clarify the intention of the myth or the mythical manner of speaking, in other words, its intention to say something about human existence.

Clarifying the mythical manner of speaking also applies to the pronouncements about God's actions with humankind. Like Kant and Schleiermacher, Bultmann does not want to objectify and humanise or reify God. But no one (including the writers of the Bible) can speak about God in anything but "objectifying language". A mythical manner of speaking about God is therefore speaking objectifyingly about the actions of God (who is not an object) with people. All speaking about the actions of God is therefore a mythical manner of speaking. The actions of God cannot be objectively proven. They can only be experienced and seen in the effects these actions have on the existential involvement of human beings in them. Human beings cannot do anything else but speak mythically about God as Creator and Lord of nature and history. We have to demythologise precisely because the Christian message is not bound to the old worldview of the Scriptures. No worldview is final, nor therefore is the Biblical. The Christian message is not oriented towards theoretical understanding but towards "den Hörer als ein Selbst".

This means that through the meeting with Christ or with the Word that proclaims him, the world and the history of the world will come to an end and the faithful will be entweltlicht as a new creation - in other words, can become independent of the sensory, finite world, free from the bonds of cause and effect in this world that determines humankind's finiteness. So when eschatology, emanating from the old mythological, apocalyptic worldview, becomes demythologised, it no longer relates to the physical end of history and the history of humankind is no longer a function of world history, but lies on the other side of world history. In so far as the faithful are entweltlicht by their faith, they are already living eschatologically (with Christ) even though they are still part of profane history. Through their faith in Jesus Christ, human beings are already new human beings at every moment when they come anew to a decision about faith.

The value of Bultmann's hermeneutic principles is seen in the fact that he rejected historism. The Scriptures can only be interpreted in such a way that it is understood as the addressing Word, as preaching. A scientific interpretation of the Scriptures is not without bias, because it questions the intention of the text. Nor can it be denied that Bultmann's existential interpretation of the Scriptures placed the Biblical text in a new light and posed new challenges to faith. It brought the important insight that faith does not mean holding up propositions as given truth but that it is a living existential relationship with God; and also that 
faith should not be seek as a habitus (a state of affairs) but invariably has to be a new existential experience of salvation in every moment's decision of faith (i.e., to believe). Equally, it cannot be denied that Bultmann's opinion about eschatology opened up new perspectives. He placed eschatological existence, which in reality became a Fernerwartung in the history of the church, in the centre of Christian life again, in the here and now.

The core of the criticism that was and still is levelled against Bultmann is, as could be expected, aimed at his demythologising programme and the fact that he reduces everything in the Biblical message to Existenzverständnis.

What became known as New Hermeneutics is linked very closely to the hermeneutic insights of $E$ Fuchs and G Ebeling in the field of theology and of $H$ $G$ Gadamer in the field of philosophy. In a certain sense, this is linked to Bultmann's hermeneutics and also rests to a large extent on Heidegger's philosophy.

To Heidegger, the term hermeneutics is not an indication of the theory of understanding, but rather of the process of understanding itself. In this regard, Gadamer also states that truth cannot be obtained or achieved methodologically, but only dialectically. Strictly speaking, method is not able to reveal new truth; it only brings explicitly to the fore the kind of truth that is already implicitly present in the method. In method it is the investigating subject who takes the lead, exercises control and manipulates; in dialectics it is the matter with which acquaintance is made that poses the question to which the investigating subject responds.

In New Hermeneutics much emphasis is laid on the meaning and the power of language. For Heidegger it is, as we have seen, the Dasein (being-inthe-world) which is itself expressed in language. People did not invent language and it is not the case that people express themselves in language. It is language itself which speaks and people are human in so far as they make room for the meaning that speaks, in that they respond to the speaking of meaning. People are where the voice of meaning is heard and finds a home. Therefore it is not human beings who give birth to language; on the contrary, human beings are born out of language. Language is not merely an instrument of communication among people, it is an event, it brings something into being, it is the establishment of meaning.

In junction to this, Fuchs also speaks of Sprachereignis and Ebeling of Wortgeschehen. Fuchs illustrates what is meant by Sprachereignis by pointing out that a person does not call someone "brother" simply on the basis of a biological fact. No, someone becomes a brother by calling him a brother. The relationship is confirmed by calling someone this, it becomes a reality. Language can then also be described as admitting, in that it allows something to enter into 
true being. Language also assembles, brings people together. Theologically speaking, this means that the proclamation is a language event in that it brings the congregation together, brings the body of Christ into being. Fuchs and Ebeling therefore see language as much more than the provision of information. We must not ask what words contain but what they bring into being. It is something different for example to speak about faith than that words engender faith.

It is of the utmost importance to both Fuchs and Ebeling that the text of the Bible should speak anew to today's people in order to engender faith. This was the way in which it originally came to its listeners. Today, so they think, too much faith is assumed and the proclamation becomes merely a repetition of what is traditionally believed. But how can the text be brought to the point where it speaks anew to the people of today? The text must be translated for the people of today. This, however, does not mean that the original words can be repeated without further ado. Simply repeating the original words may mean that they say absolutely nothing to people in their present circumstances.

For this reason, Ebeling states that the same word of the text can only be said in an intelligible way for another time if it is said differently. We have already pointed out that a text from the past spoke in the text's own historical framework with everything it comprised, and that it can only be made intelligible in another framework by taking into account the conditions for understanding that the new framework requires. This requirement is a gravely serious matter for New Hermeneutics. Not only must the matter of the text be brought to speech, the place must also be found where this matter can address one today. Hermeneutics is for New Hermeneutics the theory of understanding, not a collection of rules. Yet it is not solely about hermeneutics as a theory but as the practice of making understanding possible. Hermeneutics does not say what is understood, but is an aid to bringing understanding about. According to Ebeling, hermeneutics is really only necessary where something impedes the speaking of the text with the result that it cannot be understood. The text (or word) has itself a hermeneutic function. If the word-events occur normally, they need no aid to be understood, but are themselves an aid to understanding.

We have already pointed out that Bultmann believes that an essential assumption for understanding is the preceding life-relationship and life context of the exegete/reader with regard to the matter the text is concerned with. More or less in concurrence with this, Fuchs states that it is essential for the exegete/reader to be involved (beteiligt) in order to make a conversation possible, and therefore to make understanding possible. He calls this involvement Einverständnis. It is the willingness to become involved, the establishment and presence of a common ground for the conversation. He 
illustrates this involvement or common/mutual understanding (comprehension) on the basis of the situation in a home (family). "At home one does not speak so that people may understand, but because people understand." It is also clear from this that for Fuchs the use of language is not as much about the content of words but more about the language event. He states that the importance of the principle of Einverständnis can be seen in the words of Jesus, especially in the parables. Jesus made use, especially in the parables, of language through which $\mathrm{He}$ involved his listeners, by using familiar images and examples from everyday life. Through Einverständnis the horizons of the worlds of speaker and hearer meet each other and they merge to bring into existence a common world or terrain of understanding. Through this, a new world arises, and through this new world people's old world is changed and their old norms and preferences are brought to an end. An example of this can also be clearly detected in the parables. The parables create a new world for the listeners in which they find that the roles have been inverted and that their previous convictions and judgements are shown to be useless or wrong, and they are brought to different insights. Now they have to decide or choose in a completely new situation.

We have already commented that various people engaged in the hermeneutic question have stated that there is no possibility of any question of presuppositionless exegesis. This is also the conviction of New Hermeneutics. The principle of the so-called empty head is therefore rejected as naive and absurd. Besides the fact that exegetes/readers form part of a historical reality which determines their actions and from which they cannot free themselves or think independently. New Heremeneutics' point of departure is the fact that communication supposes a dialogical relation. This essentially sounds like something paradoxical, namely that that which must be understood, must already be known. Because exegetes/readers are part of a historical tradition, it is inevitable that prejudices (Vorurteile) will be present among them. Gadamer asserts that these prejudices of the individual, rather than his or her judgements, are the historical reality of his or her existence. Being aware of these prejudices that are based on the historical and cultural sphere in which exegetes/readers find themselves, they are however also aware of the distance in time and circumstances between their time and the time in which the text originated. Only if exegetes/readers are aware of this distance, can they extend the horizon of their world until it merges with that of the text. Only then is Einverständnis possible and so a dialogue of question and answer between the exegete/reader and the text can arise. But this does not mean that the exegete/reader may be blind to what has already been built up traditionally around the text and which may obstruct access to the text. Exegetes/readers must also be able to distance themselves from all traditional interpretations which do not do justice to the text. 
In New Hermeneutics, too, an inversion of the subject-object-scheme occurs. Here, too, the text is seen as the real subject and the exegete/reader as the object. According to Fuchs, the truth has ourselves as object and the text has first to translate us before we can translate the text. The text sheds light on the experiential world of exegetes/readers and helps them to understand it. It has already become clear from what has so far come to the fore from the insights of New Hermeneutics that for this approach, too, the process of understanding takes place in a circular course between exegete/reader and text, the so-called hermeneutic circle. Exegetes/readers go to the text with their preliminary questions. Their questions will probably not be correct in all respects, but the text has its turn to speak and shed light on their particular situation. They are hereby enabled to put their questions differently or to formulate them better, and the more appropriate their questions, the more understandable and clearer are the text's answers to the questions. In this way the exegete/reader is invariably better enabled not only to put questions to the text about the matter concerned, but the voice of this subject matter also speaks more strongly and clearly into the situation of the exegete/reader.

And this is in the essence of hermeneutics: the text from the past must speak anew in the present, in today's situation. It must interpret the present, shed light on the here and now, and in so doing become a speaking event in the present. In this way, the language of the text makes existence an event. At this point we think again about Fuchs's view that the exegete's / reader's selfunderstanding is the aim of the hermeneutic process.

Some of the most important points of criticism against the approach of New Hermeneutics are the following:

- $\quad$ Although New Hermeneutics focuses on a "deeper understanding" of the text, it is not as strongly attuned to understanding the text correctly. This objection rests mainly on the view that New Hermeneutics reduces the historical-critical activity to a mere preliminary stage of exegesis, so justice cannot be fully done to it in the whole process of interpretation. This dilution of the historical-critical investigation is seen as the result of a too-biased inversion of the subject-object scheme, through which the exegete/reader becomes too much of a listener and does not look critically enough at the text to make sure that what he or she hears, is really the truth in respect of what the text wants to say. The exegetes/readers are thus too passive and there is a great danger that what they hear will not be the intention of the text. By not approaching the text critically enough, it may happen that the language event or speaking event becomes completely meaningless. 
- $\quad$ Furthermore, New Hermeneutics is accused of using the New Testament selectively. Emphasis is given to sections such as psalms, confessions and parables in which the speech event comes strongly to the fore, whereas argumentative sections do not get much attention. Sections of the New Testament that appear to New Hermeneutics to be early patristic tradition are similarly pushed aside. It is pointed out to New Hermeneutics that it is precisely the theological tradition already present in the New Testament that is proof that the text of the New Testament is aimed not only at unbelievers but also at people who have already professed their faith and have stood in the tradition of faith. This means that the New Testament text is therefore not only aimed at creating faith as languageevent, but also at sustaining already existing faith.

- A third point of criticism concerns the view that New Hermeneutics has about language. The objection is that, as among primitive tribes, a magical character is accorded to language and language is placed on a par with the reality of being itself, something which it simply is not. Although language does indeed give shape to the way in which a community observes and orders reality, the use of language rests on the other hand, on a number of rules and customs of the community that employs the language. The word itself is not a thing but only a symbol or sign indicating the thing. The power that New Hermeneutics assigns to language therefore leads to serious attention been given only to imperative, directive language, whereas descriptive or informative language is ignored. This rests on the conviction that the real nature of words is not enclosed in what they contain, but in the effect that they have. This view of New Hermeneutics is criticised on the basis that descriptive or informative language cannot be rejected as having no value for faith.

- Conservative theologians in particular have objections to the way in which New Hermeneutics goes about the Selbstverständnis of the exegete/reader. The objection rests on the conviction that New Hermeneutics makes what is true for the exegete/reader, the criterion for what is true. A view such as this, it is thought, reduces theology to a voluntary human-centred matter which depends on the subjective judgement of the exegete/reader. Everyone can then simply understand as he or she wishes, and this is set on a par with what the text wants to say. Together with this criticism, the hermeneutic circle also comes under fire. The principle of the hermeneutic circle, so it is alleged, places the text and the experience of the exegete/reader in an untenable common relationship to each other, as if the two were on the same level. 
- $\quad$ The inversion of the subject-object scheme by New Hermeneutics and the emphasis placed on the imperative that justice must be done to the text, and that exegetes/readers should not transfer their ideas to the text, as may happen in the traditional subject-object approach, is regarded as one-sided. The opinion is that this one-sidedness does not allow New Hermeneutics to do justice to the inevitable necessity that the text nevertheless must be researched as object or subject of investigation. There is essential knowledge or information that can only be obtained in this way, and this aspect of the endeavour to understand may not be neglected or negated.

\section{KARL BARTH'S LEGACY}

From the description of the influence that the Aufklärung of the nineteenthcentury had on twentieth-century theologians, it has in my view become clear that especially two of the insights that came to the fore in hermeneutic consideration during the second half of the nineteenth century figured prominently in the twentieth century. This can be seen not only in the thoughts of Bultmann (and the exponents of the so-called New Hermeneutics) but also in those of Karl Barth.

It cocerns namely in the first place the distinction that Dilthey draws between understanding in the human sciences and explaining in the natural sciences; but then also the inversion of the subject-object scheme. To the natural sciences it is a matter of course that investigators as subjects put questions to the object of their investigation, as object, and in this way try to master the object. In hermeneutics the conviction has however taken hold that in the process of understanding a text, this subject-object scheme cannot continue to be maintained. Here the investigator (reader) is not the subject but the object, and vice versa. He or she must as object listen to what the text as subject has to say to him or her.

In a debate with Adolf von Harnack ${ }^{11}$ (1851-1930) who still advocated the natural science subject-object scheme, also for the interpretation of the Scriptures, Barth stated that it should be remembered that the Biblical text as object was first (and the first) subject, and that it must always be the subject again. It is therefore the object that now, as subject, puts questions to the subject, now the object. This questioning not only applies to the formal level, namely whether the exegete asks the right questions, but also the material level,

\footnotetext{
${ }^{11}$ See, e.g., A von Harnack [1999], Das Wesen des Christentums, herausgegeben und kommentiert von T Rendtorff.
} 
namely the question as to whether the text's answers enlighten the exegete, in other words whether the exegete understands his or her own existence in the same way as the text understands existence.

Barth himself did not produce a worked-out hermeneutic theory, but he did say enough in his foreword(s) to his commentary on the Epistle to the Romans and in his other publications to give us a good impression of his thoughts in this regard. His view of the Scriptures must be taken as the point of departure for the question of his hermeneutic views. He approaches the Scriptures as an analogy of the person of Christ who through his incarnation united God and man in Himself. This implies that against the backdrop of the incarnation the Scriptures are to be understood as a unity of God's Word and humankind's word. Both are significant. The Word of God is distinguished from the word of humankind but is at the same time one with the word of humankind. There is a relationship of indirect identity between the human Scriptural word and the revelatory Word of God. ${ }^{12}$ In other words, although the human word is not identical with God's Word, God speaks to us in this concrete human word, not behind it or next to it or in a sphere which we still have to discover.

But the testimony of the Bible is not itself the matter about which it testifies, since it is only the human testimony of it. And yet it is in this human word that God addresses us. God says now what this text says here; God's work takes place through this text. The text can therefore only be heard in the actual obedience to this addressing by God, and in faith's expectation that God will in God's freedom reveal God's Word to us. This is theological exegesis. To Barth, theological exegesis implies that the reader of the Old and New Testament will remember that the church has until now heard the Word of God in this book, and that the church will have the expectation of itself hearing the Word of God here in the present situation. Theological exegesis is located between this remembrance and expectation.

Barth could not reconcile himself to the purely historical-critical investigation of the Scriptures. In his foreword to the first edition of his commentary on the Epistle to the Romans, he states that if he had to choose between the historical-critical method and the old doctrine of inspiration, he would choose the latter. However, he does not regard it as necessary to make a choice, since historical investigation is to him the preparation for understanding the text. We must read the Bible historically, but in such a way that we understand what it is about. All interpretation must be guided by the matter that the text is about. The gap between the Bible and our understanding of it is,

\footnotetext{
${ }^{12}$ See inter alia G Plasger (2000), Die relative Autorität des Bekenntnisses bei Karl Barth, esp pp 9-30.
} 
however, just as vast as that between human understanding and God. For this reason, this gap can only be bridged by the Spirit. The word of God given through the Spirit, can only be understood with the help of the Spirit. God can only be known through God. According to Barth, it is the intention "durch das Historische hindurch zu sehen in den Geist der Bibel, der der ewige Geist ist".

Barth with all emphasis regarded the pneumatic dimension as the conditio sine qua non for understanding the Bible. The Spirit's communicating of the Word of God is, however, in a certain sense independent of all ordinary processes of human comprehension. One can namely only be confronted and illuminated by the Word of God as truth and reality if it is seen as contrary to humans' whole natural ability to understand. Barth therefore wants the Bible to be read, understood and interpreted historically. But he rejected what he regarded as the problem of historism in the historical-critical paradigm, namely that the historical realities or "facts" behind the text are seen as the things in which revelation is contained, instead of seeing revelation as contained in the text itself. In his opinion, in historism the emphasis is placed on the Bible's historical situation at the expense of its theological message. He wanted to link the study of the historical background of the Bible up with the interpretation of its theological message.

In short, Barth wanted the text's Sitz im Leben to correlate with the text's Sitz im Wort, with the emphasis on the latter. To him, it was not only about a question of the pious mood of the Biblical author but also the matter concerned, and that is the testimony of the revelation of God. Barth replaced the religious person with the revelation of God. He set the total otherness of God against the religious optimism of Liberal Theology and its opinion about the camaraderie between God and humankind. Revelation is to him that process in which it pleases the sovereign God to make God self known to humankind. God is not a human being, not even a perfect human being. The human being must know his or her place, and that is to wait on the revelation of God. This does not mean that human beings must passively await this revelation, but the fact is that people do not have any control over it. Nor to Barth can there be something like presuppositionless exegesis (voraussetzungslose Exegese). The exegete cannot initially approach the text neutrally to analyse it historicallypsychologically and only then listen to the Word of God.

There are not two stages in exegesis, there is only one truth. Therefore there cannot be another reality underlying the text before asking about the matter itself. For this reason, Barth rejects the so-called "pneumatic exegesis" as a second stage, and therefore the hermeneutic dualism of "scientific" and "practical" interpretation. Through this he reclaims the inner unity of the 
interpretation of the Scriptures. Barth also rejects the intention fallacy. The text and the author are not the same thing. Even if we had access to what the author might have meant to say, it still would not enable us to understand everything that the text might currently mean for the present reader. The meaning of the text does not lie in the historical realities of the author's intention behind the text, but in the language-specific realities that are at issue in the text. Barth was furthermore of the opinion that the Biblical text, and therefore every text, does not possess a specific meaning which only has to be extracted from it (the socalled Cinderella fallacy). Yet, the Bible is not wholly unstable as a radically acentric différance. It is indeed an open and diffuse intertext, but the meaning of the Bible is not for ever played on a bottomless chessboard without boundaries or limits. On the other hand, readers never have a guarantee that they have reflected the intention of the text correctly. It is only the promise of the Spirit's presence in the process of interpretation that makes the true transference of the Biblical content possible.

In conclusion, it was clear to Barth that there could not be anything like "Biblical" hermeneutics in contradistinction to "profane" hermeneutics. Therefore there is no such thing as a "sacred" compared to a "profane" way of understanding. Some of the winning points of Barth's hermeneutics are that he made the text the subject of communication events, that he emphasised the matter concerned in the text and rejected the intention fallacy, the double meaning of the Scriptures and presuppositionless exegesis, and lastly that he saw that there was no such thing as a fixed, given meaning of a text. The most important misgiving, however, remains Barth's negative attitude towards historical criticism and as a result, his reading of things into texts which could not withstand the test of historical investigation. Barth's Christological analogy for explaining the relationship between God's Word and the human word in the Bible is more inventive than convincing.

Not only did Paul Ricoeur's hermeneutic arch idea offer a corrective to Barth's unconvincing application of the hermeneutic circle, it was also shown to be biased, especially through the critical theory of the so-called Frankfurt School. In this regard, Jürgen Habermas played a significant role. Critical theory was in fact meant as an alternative to the traditional hermeneutic approach of someone like Barth. The consensus principle (merging of horizons) was not unquestioningly accepted without further ado (see Klemm 1986:203-208). This hermeneutic approach proceeds from the assumption that a "merging of the horizons" occurs in the communicative interaction between subject and object and that an exchange of roles occurs at the same time. Object is subject. An illustration of the problem is that if the object has for example internalised pain owing to system relations, an exchange of roles 
cannot of itself entail that the experience of pain is recognised and identified as a problem. On the contrary, precisely because the object which is the bearer of pain now gains the status of subject, the possibility of recognition becomes even further obscured.

This is an example of the problematics surrounding the concept of "role exchanging" in Barth's hermeneutics, in spite of his having had a dynamic perspective on the Scriptures. We have seen that to him the Bible was not in the direct sense of the word equal to God's revelation. Otto Weber (1967:16) points out that the Bible only became Revelation to Barth "wo das Bibelwort als Zeugenwort in Funktion tritt." One can only then speak of God's revelation when the Bible is heard in word events: "Sie muß Gottes Wort je und je werden." Such "events" (Ereignis) can be seen as erfüllte Zeit which mit Jesus Christus identisch ist. The problem lies, however, in the possibility that this dynamic view of the Scriptures may become enervated if it does not touch ground existentially. For this reason, the comment that $\mathrm{H}$ Zahrnt makes in his book Die Sache mit Gott, should be taken to heart. Zahrnt ${ }^{13}$ criticised Barth's theology because it often came across as "Monolog im Himmel". It seems to me that this can be ascribed to the fact that the role exchanging "subjectobject" was not in essence for Barth a subject-subject relationship, but was still in the converse sense of the word a subject-object relationship. For Barth the Biblical text is the object first (and the first) subject and always has to become the subject again. It is therefore the object that now as subject, puts questions to the subject, now the object. For this reason, Barth can without reservations speak of the "Freiheit des Wortes", without becoming aware that when God's Word is communicated in a word event, the existing distorted communication in the Scriptures - because of explicit of sublimed patriarchalism or, among other things, gender inequality or the abuse of power - can be conveyed as normative.

Because God's Word (the subject) has a "freedom" which people (the object) cannot place in bonds, Barth speaks in terms of "power" when he refers to the "authority" of the Scriptures. The insight into the fact that communication can be distorted by the search for one's own interest in power, dawned only in the post-Aufklärung era. In my opinion, discounting any abuse of power in the Biblical discourse is a condition for really speaking of communication on a subject-subject axis. Something of the breakthrough that this insight made in the hermeneutic approach can in fact be seen in HansGeorg Gadamer. When Gadamer ([1990] 1999), the pioneer of the new hermeneutic approach, applies the hermeneutic circle concept (i.e. the concept of "role exchanging") to the interaction with the Bible, he sees that

\footnotetext{
${ }^{13}$ H Zahrnt ([1966] 1967), Die Sache mit Gott: Die protestantische Theologie im 20. Jahrhundert, $\mathrm{p} 141$.
} 
being subjected to the Bible should not be an issue of dominance on the part of the Bible but rather as a matter of serving.

In the postmodern discourse of thinkers such as Emmanuel Levinas, Theodor W Adorno and Michel Foucault, ${ }^{14}$ the emphasis does not lie as such on understanding, but on experiencing. They recognise it as a problem in communication when "objects" are reified or reduced to superficiality owing to objectivising it to non-identity and experiencing it as painful. This critical hermeneutics has as goal the emancipatory cognitive interest. This "interest" wants to promote and encourage a society free from distorted communication which conveys the abuse of power through totalitarianism. The words "promote" and "encourage" are important here. Sometimes the likes of Habermas is criticised for the fact that his critical theory would essentially be a utopia, because in this broken world a condition of ideal egalitarianism could never be attained.

However, critical theory is in this regard different from classical Marxism. ${ }^{15}$ In fact, it originated within the neo-Marxist school that criticised Marx's idea of a classless society. Critical theory does promote and encourage the ideal of non-manipulation and exploitation. ${ }^{16}$ By means of this critical theory, people are made aware that the ideal has not been actualised. That is why critical theory calls on people to be continuously, in all societies, critically attuned to manipulation and exploitation. ${ }^{17}$ In the words of Jacques Derrida $^{18}$ (concurring with both Immanuel Kant's idea of the categorical imperative and Emmanuel Levinas' idea of the infinite responsibility):

How, then, are we to interpret this impossibility [of establishing a seemingly symmetrical discourse] .... Does this impossibility signal a failing? Perhaps we should say the contrary. Perhaps we would, in truth, be put to another kind of test by the apparent negativity of this lacuna, this hiatus between ethics ..., on the one hand, and, on

\footnotetext{
${ }^{14}$ See, e.g., E Levinas ([1982] 2006), Bible and philosophy, [and] Responsibility for the Other, [and] The hardness of philosophy and the consolation of religion, in Ethics and infinity: Conversations with Philippe Nemo, tr by R A Cohen, 19-34, [and] 93-102, [and] 111-122 (cf G A Phiilips 2000, s v Levinas, in, A K M Adam ed, Handbook of postmodern Biblical interpretation, 154-159); T Adorno ([1967] 1981), Prisms, tr by Samuel \& Shierry Weber (cf C J Beukes 1996, Anderbereddering: Met Adorno by die hartslag van die post moderne intellek, 68-87); M Foucault ([1969] 1972), Archaeology of knowledge (cf M K George 2000, s v Foucault, in Adam, A K M ed, Handbook of postmodern Biblical interpretation, 91-98).

${ }^{15}$ See, e.g., H Hoefnagels ([1974] 1976), Kritische sociologie: Inleiding tot het sociologisch denken der "Frankfurter Schule".

${ }^{16}$ Seem e.g. N Adams (2006), Habermas and theology. Cambridge, pp 106-123.

${ }^{17}$ See, e.g., A Wellmer (1976), Communication and emancipation: Reflections on the linguistic turn of critical theory, in J O'Neill (ed), On critical theory, 231-263.

18 J Derrida ([1997] 1999, Adieu to Emmanuel Levinas, tr by P-A Brault \& M Naas, pp 20-21 (cf Hent de Vries 2001, Derrida and ethics: Hospitable thought, in T Cohen (ed), Jacques Derrida and the humanities: A critical reader, 172-192).
} 
the other, law or politics ... Would it not in fact open - like a hiatus both the mouth and the possibility of another speech, of a decision and a responsibility .... where decisions must be made and responsibility, as we say, taken without the assurance of an ontological foundation? (Derrida's emphasis).

This standpoint links up theologically with the perspective of a person such as the apostle Paul. Paul always goes from the indicative of salvation and calls the faithful to become what they already are. Therefore there is always an imperative; although salvation is proclaimed, it is in this broken world only audible to the ear of faith. Paul, from the perspective of the salvationary indicative, proclaims that there is no man or woman in Christ. Here, in the postmodern sense, one finds the ideal of "egalitarian symmetry". In today's context, hermeneutics ought to have this ideal high on the list of priorities by promoting and encouraging it in any communication and interaction.

\section{Works consulted}

Adam, A K M 1995. What is postmodern Biblical criticism? Minneapolis, MN: Fortress. (Guides to Biblical Scholarship.)

Adams, N 2006. Habermas and theology. Cambridge: Cambridge University Press.

Adorno, T [1967] 1981. Prisms, tr by Samuel \& Shierry Weber. Cambridge, MA: MIT Press.

Albrecht, C 1994. Schleiermachers Theorie der Frömmigkeit: Ihr wissenschaftliche Ort und ihr sytematischer Gehalt in den reden, in der Glauibenslehre und in der Dialektik. Berlin: De Gruyter.

Apfelbacher, K-E 1978. Frömmigkeit und Wisenschaft: Ernst Troeltsch und sein theolgoisches Programm. München: Chr Kaiser Verlag.

Barth, K [1919] 1985. Der Römerbrief (Erste Fassung), neu hrsg von H Schmidt. Karl Barth Gesamtausgabe, II: Akademische Werke. Zürich: EVZ Verlag.

Barth, K 1922. Der Römerbrief. Zweite Auflage in neuer Bearbeitung. München: Chr Kaiser Verlag.

Barth, K [1924] 1966. Biblische Fragen, Einsichten und Ausblicke, in Moltmann, J (Hrsg), Anfänge der dialektische Theologie, Teil 1: Karl Barth, Heirich Barth, Emil Brunner, 49-76. 2. Auflage. München: Chr Kaiser Verlag. (TB 17/1.)

Barth, K 1925a. Das Schriftprinzip der Reformierte Kirche. ZZ3, 215-245.

Barth, K [1925b] 1966. Das Wort Gottes als Aufgabe der Theologie, in Moltmann, J (Hrsg), Anfänge der dialektische Theologie, Teil 1: Karl Barth, Heirich Barth, Emil Brunner, 197-218. 2. Auflage. München: Chr Kaiser Verlag. (TB17/1.)

Barth, K 1925c. Die neue Welt in der Bibel, in Das Wort Gottes und die Theologie, 18-32. München: Chr Kaiser Verlag. 
Barth, K 1926. Die Auferstehung der Toten: Eine akademische Vorlesung über 1. Kor. 15. 2. Auflage. München: Chr Kaiser Verlag.

Barth, K 1932. Die Kirchliche Dogmatik, Band 1: Die Lehre vom Wort Gottes. Prolegomena zur Kirchliche Dogmatik. Erster Halbband (KD 1.1). München: Chr Verlag.

Barth, K 1945. Die Kirchliche Dogmatik, Erster Band: Die Lehre vom Wort Gottes. Prolegomena zur Kirchliche Dogmatik. Zweiter Halbband. 3. Auflage (KD 1.2). Zürich: EVZ.

Barth, K 1947. Die protestantische Theologie im 19. Jahrhundert: Ihre Vorgeschichte und ihre Geschichte. Zürich: EVZ.

Barth, K 1952. Rudolf Bultmann: Ein Versuch, ihn zu verstehen. Zürich: EVZ Verlag. (ThSt 34.)

Baur, F C 1847. Lehrbuch der christliche Dogmengeschichte. Stuttgart: B G Treubner.

Beukes, C J 1996a. Anderbereddering: Met Adorno by die hartslag van die post moderne intellek. HTS 52, 68-87.

Birkner, H-J 1959. "Offenbarung" in Schleiermachers Glaubenslehre, in Fisher, H (Hrsg), Schleiermacher-Studien, 81-99. Eingelatet und herausgegeben von $\mathrm{H}$ Fischer. Berlin: De Gruyter.

Birus, H 1982. Zwischen den Zeiten: Friedrich Schleiermacher als Klassiker der neuzeitliche Hermeneutik, in Hermeneutische Positionen, 15-58. Göttingen: Vandenhoeck \& Ruprecht.

Bowie, A (ed) 1998. Hermeneutics and criticism and other writings. Cambridge: Cambridge University Press. (Cambridge Texts in the History of Philosophy.)

Bromiley, G W 1979. An introduction to the theology of Karl Barth. Grand Rapids, MI: Eerdmans.

Bultmann, R [1926] 1988. Jesus. Neuausgabe. Tübingen: Mohr Siebeck.

Bultmann, R [1933a] 1993. Die Bedeutung der "dialektischen" Theologie für die neutestamentliche Wissenschaft, in Glauben und Verstehen: Gesammelte Aufsätze, Erster Band, 114-133. Neunte Auflage. Tübingen: Mohr. (UTB 1760.)

Bultmann, R [1933b] 1993. Die Bedeutung des geschichtlichen Jesus für die Theologie des Paulus, in Glauben und Verstehen: Gesammelte Aufsätze, Erster Band, 188-213. Neunte Auflage. Tübingen: Mohr. (UTB 1760.)

Bultmann, R [1933c] 1993. Die Christologie des Neuen Testaments, in Glauben und Verstehen: Gesammelte Aufsätze, Erster Band, 245-267. Neunte Auflage. Tübingen: Mohr. (UTB 1760.)

Bultmann, R [1933d] 1993. Die liberale Theologie und die jüngste theologische Bewegung, in Glauben und Verstehen: Gesammelte Aufsätze, Erster Band, 1-25. Neunte Auflage. Tübingen: Mohr. (UTB 1760.)

Bultmann, R [1933e] 1993. Welchen Sinn hat es, von Gott zu reden?, in Glauben und Verstehen: Gesammelte Aufsätze, Erster Band, 26-37. Neunte Auflage. Tübingen: Mohr. (UTB 1760.)

Bultmann, R [1941] 1988. Neues Testament und Mythologie: Das Problem der Entmythologisiering der neutestamentliche Verkündigung. Nachdruck der 1941 erschienen Fassung, hrsg von E Jüngel. München: Chr Kaiser Verlag. (BevTh 96.) 
Bultmann, R [1948-1953] 1984. Theologie des Neuen Testaments. 9. Auflage, durchlesenhen und ergänzt von O Merk. Tübingen: Mohr. (UTB 630.)

Bultmann, R [1949] 1992. Das Urchristentum im Rahmen der antiken Religionen. 5. Auflage. München: Chr Kaiser Verlag.

Bultmann, R 1952. Das Problem der Entmythologisierung, in Bartsch, H W (Hrsg), Kerygma und Mythos, Band 2, 179-208. Hamburg: Reich \& Heidrich, Evangelischer Verlag.

Bultmann, R [1961a] 1993. Der Begriff der Offenbarung im Neuen Testament, in Glauben und Verstehen: Gesammelte Aufsätze, Dritter Band, 268-293. Vierte, unveränderte Auflage. Tübingen: Mohr. (UTB 1762.)

Bultmann, R [1961b] 1993. Ist voraussetzungslose Exegese möglich?, in Glauben und Verstehen: Gesammelte Aufsätze, Dritter Band, 142-150. Vierte, unveränderte Auflage. Tübingen: Mohr. (UTB 1762.)

Bultmann, R [1965] 1993. Antwort an Ernst Käsemann, in Glauben und Verstehen: Gesammelte Aufsätze, Vierter Band, 190-198. Vierte, unveränderte Auflage. Tübingen: Mohr. (UTB 1762.)

Bultmann, R [1965] 1993. Antwort an Ernst Käsemann, in Glauben und Verstehen: Gesammelte Aufsätze, Vierter Band, 190-198. Vierte, unveränderte Auflage. Tübingen: Mohr. (UTB 1762.)

Bultmann, R 1967a. Das Problem einer theologische Exegese des Neuen Testaments, in Moltmann, J (Hrsg), Anfänge der dialektischen Theologie, Teil II: Rudolf Bultmann, Friedrich Gogarten, Eduard Thurneysen, 47-71. 2. Auflage. München: Chr Kaiser Verlag. (TB 17/2.)

Bultmann, R 1967b. Die Frage der "dialektische" Theologie, in Moltmann, J (Hrsg), Anfänge der dialektischen Theologie, Teil II: Rudolf Bultmann, Friedrich Gogarten, Eduard Thurneysen, 72-92. 2. Auflage. München: Chr Kaiser Verlag. (TB 17/2.)

Bultmann, R [1968] 1993. Das Problem der Hermeneutik, in Glauben und Verstehen: Gesammelte Aufsätze, Zweiter Band, 211-235. Sechste Auflage, unveränderter Nachdruck der fünften Auflage. Tübingen: Mohr. (UTB 1761.)

Bultmann, R 1971. Brief an Rudolf Bultmann, in Beintker, J et al (Hrsg), R Hermann: Bibel und Hermeneutik: Gesammelte und Nachgelassene Werke, Band 3, S. 297. Göttingen: Vandenhoeck \& Ruprecht.

Bultmann, R [1984] 1993, Jesus Christus und die Mythologie, in Glauben und Verstehen: Gesammelte Aufsätze, Vierter Band, 141-189. Fünfte Auflage, unveränderter Nachdruck der 4. Auflage mit Register zu Band i-IV von Michael Lattke. Tübingen: Mohr. (UTB 1762.)

Burnett, R E 2001. Karl Barth's theological exegesis. Tübingen: Mohr Siebeck. (WUNT.)

Busch, E 1075. Karl Barths Lebenslauf: Nach seinen Briefen und autobiographische Texten. München: Chr Kaiser Verlag.

Campbell, J 1972. Myths to live by. New York: Bantam.

Claussen, J H 1997. Die Jesus-Deutung Ernst Troeltsch im Kontext der liberalen Theologie. Tübingen: Mohr Siebeck. (BHTh 99.)

Crouter, R 2005. Friedrich Schleiermacher: Between enligthenment and romanticism. Cambridge: Cambridge University Press.

Dawson, R D 2007. The resurrection in Karl Barth. Hampshire: Ashgate. (Barth Studies.) 
Derrida, J [1997] 1999. Adieu to Emanuel Levinas, tr by P-A Brault \& M Naas. Stanford, CA: Stanford University Press.

De Vries, H 2001. Derrida and ethics: Hospitable thought, in T Cohen (ed), Jacques Derrida and the humanities: A critical reader, 172-192. Cambridge: Cambridge University Press.

Dilthey, W [1960]. Zur Preussischen Geschicte, in Wilhelm Diltheys Gesammelte Schriften, Band 12. 3. Auflage. Stuttgart B G Teubner

Dilthey, W [1972]. Leben Schleiermachers, Redeker, von M (Hrsg) in Wilhelm Diltheys Gesammelte Schriften, Band 13. Göttingen: Vandenhoeck \& Ruprecht.

Drescher, H-G 1991. Ernst Troeltsch: Leben und Werk. Göttingen: Vandenhoeck \& Ruprecht.

Duling, D C 1979. Jesus Christ through history. New York: Harcourt Brace Jovanovich.

Ebeling, G 1950. Die Bedeutung der historisch-kritische Methode für die protestantische Theologie. ZThK 47, 1-46.

Ebeling, G 1959. Wort Gottes und Hermeneutik. ZThK 56, 224-251.

Ebeling, G 1962. Theologie und Verkündigung: Ein Gesprach mit Rudolf Bultmann. Tübingen: Mohr Siebeck. (HUTh 1.)

Ebeling, G 1966. "Sola Scriptura" und das Problem der Tradition, in Gottes Wort und Tradition: Studien zu einer Hermeneutik der Konfessionen, 91-143.

2. Auflage. Göttingen: Vandehoeck \& Ruprecht.

Ebeling, G 1978. Schrift und Erfahrung als Quelle theologischer Aussagen. ZThK 75, 99-116.

Ebeling, G 1981. Wiederentdeckung der Bibel in der Reformation - Verlüst der Bibel heute? ZThK 5, 1-19.

Ebeling, G [1994] 1995. Hermeneutik zwischen der Macht des Gotteswort und seiner Entmachtung in der Moderne, in Theologie in den Gegensätzen des Lebens, 209-225. Tübingen: Mohr Siebeck. (Wort und Glaube 4.)

Ebeling, G 1995a. Befreiende Autorität: Schrift, Wort und Geist im Sinne der Reformation, in Theologie in den Gegensätzen des Lebens, 313-318. Tübingen: Mohr Siebeck. (Wort und Glaube 4.)

Ebeling, G 1995b. Dogmatik und Exegese, in Theologie in den Gegensätzen des Lebens, 492-508. Tübingen: Mohr Siebeck. (Wort und Glaube 4.)

Evang, M 1988. Rudolf Bultman in seiner Frühzeit. Tübingen: Mohr Siebeck. (BHTh 74.)

Fann, K 1970. Peirce's theory of abduction. The Hague: Martinus Nijhof.

Foucault, M [1969] 1972. Archaeology of knowledge, tr by A M Sheridan Snith. London: Routledge.

Frör, K 1967. Biblische Hermeneutik: Zur Schriftauslegung in Predigt und Unterricht. Dritte, überarbeitete Auflage. München: Chr Kaiser Verlag.

Fuchs, E [1946] 1965. Die Aufgabe der neutestamentliche Wissenschaft für die krirchliche Verkündigung heute, in Zur Frage nach dem historische Jesus: Gesammelte Aufsätze, II, 55-65. 2. Auflage. Tübingen: Mohr Siebeck.

Fuchs, E [1954] 1970. Hermeneutik. Tübingen: Mohr.

Fuchs, E [1960] 1965. Was is ein Sprachereignis? Ein Brief, Zur Frage nach dem historische Jesus: Gesammelte Aufsätze, II, 424-430. 2. Auflage. Tübingen: Mohr Siebeck. 
Fuchs, E [1962] 1965. Alte und neue Hermeneutik, in Glaube und Erfahrung: Zum christologische Problem im Neuen Testament: Gesammelte Aufsätze, III, 193-230. Tübingen: Mohr Siebeck.

Fuchs, E 1965. Das Wesen des Sprachgeschehens und die Christologie, in Glaube und Erfahrung: Zum christologische Problem im Neuen Testament: Gesammelte Aufsätze, III, 231-248. Tübingen: Mohr Siebeck.

Fuchs, E 1968. Marburger Hermeneutik. Tübingen: Mohr Siebeck. (HUTh 9.)

Gabler, J P [1789] 1975. Von der richtigen Unterscheidung der biblischen und der dogmatischen Theologie und der rechten Bestimmung ihrer beider Ziele, in Strecker, G (Hrsg), Das Problem der Theologie des Neuen Testaments, 3244. Darmstadt: Wissenschaftliche Buchgesellschaft.

Gadamer, H-G [1961] [1986] 1999. Zur Problematik des Selbsverständnisses: Eine hermeutischen Beitrag zur Frage der Entmythologisiering, in Gesammelte Werke, 2: Hermeneutik, II: Wahrheit und Methode: Grundzüge einer philosophischen Hermeneutik, 121-132. 6. Auflage. Tübingen: Mohr Siebeck. (UTB 2115.)

Gadamer, H-G 1964. Martin Heidegger und die Marburger Theologie, in Dinkler, E (Hrsg), Zeit und Geschichte: Dankesgabe and Rudolf Bultmanns zum 80. Geburtstag, 479-490. Tübingen: Mohr.

Gadamer, H-G [1990] 1999. Gesammelte Werke, 1: Hermeneutik, I: Warhrheit und Methode: Grundzüge einer philosophischen Hermeneutik. 6. Auflage. Tübingen: Mohr Siebeck.

George, M K 2000. s v Foucault, in Adam, A K M (ed), Handbook of postmodern biblical interpretation, 91-98. St Louis, MO: Chalice.

Gräb, W 1985. Die unendliche Aufgabe des Verstehens, in Lange, D (Hrsg), Friedrich Schleiermacher 1768-1834: Theologe - Philosoph - Pädagoge, 47-71. Göttingen: Vandenhoeck \& Ruprecht.

Graf, F W 1983. Ferdinand Christian Baur (1762-1860), in Fries, H \& Kretzschmar, G (Hrsg), Klassiker Theologie, Band 2: Von Richard Simon bis Dietrich Bonhoeffer, 89-110. München: Ch Kaiser Verlag.

Graf, F W (Hrsg) 2000. Ernst Troeltschs "Historismus”. Gütersloh: Gütersloher Verlaghaus. (Troeltsch-Studien 11.)

Härle, W 1975. Der Aufruf 93 Intellektuellen und Karl Barths Bruch mit der liberalen Theologie. ZThK 72, 207-224.

Hartwell, H 1964. The theology of Karl Barth: An introduction. Philadelphia, PA: Westminster.

Hegel, G W F [1969]. Hegel's science of logic, tr by A V Miller. London: George Allen. Hegel, G W F [1986a]. Vorlesungen über die Geschichte der Philosophie, II. Werke in 20 Bänden, Werke 19. Frankfurt: Suhrkamp.

Hegel, G W F [1986b]. Vorlesungen über die Geschichte der Philosophie, III. Werke in 20 Bänden, Werke 20. Frankfurt: Suhrkamp.

Heidegger, M [1962] 1972. Being and time, tr by J Macquarrie \& E Robinson. Oxford: Blackwell.

Heidegger, M 1972. Poetry, language, thought, tr by A Hofstadler. New York: Harper. Henrich, D [1967] 1971. Hegel im kontext. Vierte, veränderte Auflage. Frankfurt: Suhrkamp.

Hodges, H A 1944. Wilhelm Dilthey: London: Routledge \& Kegan Paul. 
Hodges, H A 1952. The philosophy of Wilhelm Dilthey. London: Routledge \& Kegan Paul.

Hoefnagels, H [1974] 1976. Kritische sociologie: Inleiding tot het sociologisch denken der "Frankfurter Schule". 2. Auflage. Alphen aan den Rijn: Samson Uitgeverij. (Sociaal Politieke Verkenningen.)

Hohmeier, F 1964. Das Schriftverständnis in der Theologie Rudolf Bultmanns. Berlin: De Gruyter. (AGTL 13.)

Jaeschke, W 1986. Die Vernunft in der Religion: Studien zur Grundlegung der Religionsphilosophie Hegels. Stuttgart: B G Treubner. (Spekulation und Erfährung, Abt. 2. Untersuchungen 4.)

Joy, C R 1948. Introduction: Schweitzer's conception of Jesus, in Schweitzer, A [1913] 1948, The psychiatric study of Jesus: Exposition and criticism, translated and with an introduction by $C \mathrm{R}$ Joy, and a foreword by $\mathrm{W}$ Overholser. Boston, MA: Beacon.

Jung, C G [1956] 1967. Symbols of transformation: Collected works, vol 5. $2^{\text {nd }}$ ed. Princeton, NJ: Princeton University Press

Jüngel, E 1980. s v Barth, Karl (1886-1968). TRE 5, 251-268. Berlin: De Gruyter.

Jüngel, E 1982a. Einführung in Leben und Werk Karl Barths, in Barth-Studien, 22-60. Zürich: Benziger Verlag.

Jüngel, E 1982b. Theologie als Metakritik: Zur Hermeneutik theologischer Exegese, in Barth-Studien, 91-98. Zürich: EVZ Verlag.

Kähler, M [1896] 1969. Der sogenannte historische Jesus und der geschichtliche, biblische Christus. Neuherausgegeben von E Wolf. 4. Auflage. München: Kaiser Verlag. (TB Band 2, Systematische Theologie.)

Kant, I [1793] 1914. Die Religion innerhalb der Grenzen der bloßen Vernunft, die Metaphysik der Sitten. Kant's Werke, Band 6. Berlin: Reimer.

Kant, I [1793] 1977. Die Religion innerhalb der Grenzen der bloßen Vernunft, in Die Metaphysik der Sitten: Werkausgabe VIII, hrsg von W Weischedel, 645-879. Frankfurt: Suhrkamp.

Käsemann, E [1954] 1960. Das Problem des historischen Jesus, in Exegetische Versuche und Besinnungen, Erster Band, 187-214. Göttingen: Vandenhoeck. [Originally published in ZThK 51, 125-153.]

Käsemann, E [1964] 1969 Blind alleys in the "Jesus of History" controversy, in New Testament questions of today, 23-65, tr by W J Montague. London: SCM. (The New Testament Library.)

Klemm, D E 1986. Introduction to Habermas' On systematically distorted communication and Toward a theory of communicative competence, in Klemm, D E (ed), Hermeneutical inquiry, Vol 2: The interpretation of existence, 203-208. Atlanta, GA: Scholars Press. (AAR Studies in Religion.)

Köpf, U 1992. Ferdinand Christian Baur als Begründer einer consequent historischen Theologie. ZThK 89, 440-461.

Korsch, D 1996. Dialektische Theologie nach Karl Barth. Tübingen: Mohr Siebeck. (2. Reihe 145.)

Küng, H [1970] 1989. Menschwerdung Gottes: Eine Einführung in Hegels theologisches Denken als Prologemena zu einer künftigen Christologie. München: Chr Kaiser Verlag. (Serie Piper 1049.)

Lange, D (Hrsg) 1985. Friedrich Schleiermacher 1768-1834: Theologe - Philosoph Pädagoge. Göttingen: Vandenhoeck \& Ruprecht. 
Lauster, J 2004. Prinzip und Methode: Die Transformatie des protestantischen Schriftprinzips durch die historische Kritik von Schleiermacher bis zur Gegenwart. Tübingen: Mohr Siebeck. (Hermeneutische Untersuchungen zur Theologie.)

Lessing, E [1870-1918] 2000. Geschichte der deutschprachigen evangelischen Theologie von Albrecht Ritschl bis zur Gegenwart, Band 1. Göttingen: Vandenhoeck \& Ruprecht.

Levinas, E [1982] 2006. Bible and philosophy, [and] Responsibility for the Other, [and] The hardness of philosophy and the consolation of religion, in Ethics and infinity: Conversations with Philippe Nemo, tr by R A Cohen, 19-34, [and] 93-102, [and] 111-122. Pittsburgh, PA: Duquenesne University Press.

Liebing, H 1960. Historisch-kritische Theologie: Zum 100. Todestag Ferdinand Christian Baurs am 2. Dezember 1960. ZThK 57, 302-317.

Mariňa, J (ed) 2005. The Cambridge Companion to Friedrich Schleiermacher. Cambridge: Cambridge University Press.

Maurer, E 1989. Sprachphilosphische Aspekte in Karl Barths "Prolegomena zur Kirchliche Dogmatik". Frankfurt: Suhrkamp. (EHS T 357.)

Mouton, J 1987. Die positivisme, in Snyman, J J \& Du Plessis P G W (reds), Wetenskapsbeelde in die geesteswetenskappe, 1-29. Pretoria: RGN. (RGN-Studies in Navorsingsmetodologie 3.)

Nowak, K 2001. Schleiermacher: Leben, Werk und Wirkung. Göttingen: Vandenhoeck \& Ruprecht. (UTB 2215.)

Ochs, P 1998. Peirce, pragmatism and the logic of Scripture. Cambridge: Cambridge University Press.

Paine, T 1942. The age of reason, in Basic writings of Thomas Paine. New York: Wiley Book Company.

Painter, J 1987. Theology as hermeneutics: Rudolf Bultmann's interpretation of the history of Jesus. Sheffield: The Almond Press.

Painter, J 1987. Theology as hermeneutics: Rudolf Bultmann's interpretation of the history of Jesus. Sheffield: The Almond Press.

Pambrun, J R 2001. Hermeneutical theology and narrative. Theoforum 32(3), 273301.

Pannenberg, W 1979. Über historische und theologische Hermeneutik, in Grundfragen systematischer Theologie: Gesammelte Aufsätze, 123-158.

3. Auflage. Göttingen: Vandenhoeck \& Ruprecht.

Pannenberg, W [1996] 1999. Zur Begründung der Lehre von der Schriftinspiration, Beiträge zur Systematischen Theologie, Band 1: Philosophie, Religion, Offenbarung, 246-248. Göttingen: Vandenhoeck \& Ruprecht.

Pelser, G M M \& Van Aarde, A G 2007. The historical-hermeneutical prelude to the legacy of Karl Barth. HTS 63(4), 1347-1375.

Peirce, C 1957. The logic of abduction, in Essays in the philosophy of science. New York: The Liberal Arts Press.

Plasger, G 2000. Die relative Autorität des Bekenntnisses bei Karl Barth: NeukirchenVluyn: Neukirchener Verlag.

Philips, G A 2000, s v Levinas, in A K M Adam (ed), Handbook of postmodern Biblical interpretation, 154-159. St Louis, MO: Chalice.

Reilly, F 1970. Charles Peirce's theory of scientific method. New York: Fordham University Press. 
Rendtorff, T 1985. Ernst Troeltsch, in Greschat, M (Hrsg), Gestalten der Kirchengeschichte, Bd 10, 1: Die neueste Zeit, III, 185-203. Stuttgart: Kohlhammer.

Ricoeur, P 1970. The function of fiction in shaping reality. Man and World 12, 123141.

Ricoeur, P 1974. Philosophische und theologische Hermeneutik, in Ricoeur, P \& Jüngel, E (Hrsg), Metapher: Zur Hermeneutik religiöser Sprache, 24-45. München: Chr Kaiser Verlag.

Ricoeur, P 1976. Metaphor and symbol, tr by D Pellauer, in Interpretation theory: Discourse and the surplus of meaning, 45-69. Fort Worth, TX: The Texas Christian University Press.

Ricoeur, P 1978. The narrative function. Semeia 13, 177-202.

Ricoeur, P 1979. The metaphorical process as cognition, imagination and feeling, in Sacks, S (ed), On metaphor, 141-157. Chicago, IL: University of Chicago Press.

Ricoeur, P 1981. Hermeneutics and the human sciences: Essays on language, action and interpretation, tr and ed by J B Thompson. Cambridge: Cambridge University Press.

Ricoeur, P 1984. Time and narrative, I. London: Chigago University Press.

Ricoeur, P 1985 Time and narrative, II. London: Chigago University Press.

Ricoeur, P [1986] 1991. From text to action: Essays in hermeneutics, II, tr by K Blamey \& J B Thompson. London: Athlone.

Ringleben, J 1994. Hegels neue Philosophie des Lebens von der Bibel aus, in Ziegert, R (Hrsg), Die Zukunft des Schriftprinzips, 75-92. Stuttgart: Kohlhammer. (Bibel in Gespräch 2.)

Rohls, J 2002. Ferdinand Christian Baur: Spekulation und Christentumgeschichte, in Neuner, P \& Wenz, G (Hrsg), Theologen des 19. Jahrhunderts: Eine Einführung, 39-58. Darmstadt: Verlaghaus.

Schleiermacher, F D E [1799] 1967. Über die Religion: Reden an die Gebildeten unter ihren Verächteren, hrsg von R Otto. 6. Auflage. Göttingen: Vandenhoeck \& Ruprecht.

Schleiermacher, F D E [1927-1928] 1981. Schleiermachers Werke: Auswahl in vier Bänden, hrsg von O Braun \& J Bauer. Aalen: Scientia

Schleiermacher, F D E [1981] 1960. Der christliche Glaube, Band 1 und 2, hrsg von $M$ Redeker. 2. Auflage. Berlin: De Gruyter.

Schleiermacher, F D E [1814-1815] [1833] 1988. Einleitung zur Dialektik, hrsg von A Arndt. Hamburg: Felix Meiner. (Philosophische Bibliothek 386.)

Schleiermacher, F D E [1985]. Die Algemeine Hermeneutik, hrsg von W Virmond. Schliermacher-Archiv, vol 1.1271-1230. Berlin: De Gruyter.

Schleiermacher, F D E [1985]. Hermeneutik und Kritik, hrsg von M Frank. 6. Auflage. Franhkfurt a M: Suhrkamp.

Schlenke, D 1999. "Geist und Gemeinshaft": Die systematische Bedeutung der Pneumatologie für Friedrich Schleiermachers Theorie der christliche Frömmigkeit. Berlin: De Gruyter.

Schmithals, W 1967. Die Theologie Rudolf Bultmanns: Eine Einführung. 2. Auflage. Tübingen: Mohr. 
Schmithals, W 1996. Zu Karl Barths Schriftauslegung: Die Problematik von dogmatische und historische Exegese, in Trowitzsch, M (Hrsg), Karl Barths Schriftauslegung, 23-52. Tübingen: Mohr Siebeck.

Schnub, H 1994. Schleiermachers Hermeneutik und ihre Vorgeschichte im 18. Jahrhundert: Studien zur Bibelauslegung, zu Hamann, Herder und F Schlegel. Stuttgart: Kohlahmmer.

Scholder, K 1961. Ferdinand Christian Baur als Historiker. EvTh 21, 435-458.

Scholder, K 1966. Ursprünge und Probleme der Bibelkritik im 17. Jahrhunderts: Ein Beitrag zur Entstehung der historisch-kritischen Theologie. München: Ch Kaiser Verlag. (FGLP 10, 33.)

Schröder, M 1996. Die kritische Identität des neuzeitliche Christentums: Schleiermachers Wesensbestimmung der christliche Religion. Tübingen: Mohr Siebeck. (BHTh 96.)

Schweitzer, A [1906] 1913. Geschichte der Leben-Jesu-Forschung. Zweite, neu bearbeitete und vermehrte Auflage des Werkes Von Reimarus zu Wrede. Tübingen: Mohr (Paul Siebeck).

Schweitzer, A [1913] 1948. The psychiatric study of Jesus: Exposition and criticism, translated and with an introduction by $C \mathrm{R}$ Joy, and a foreword by $\mathrm{W}$ Overholser. Boston, MA: Beacon.

Simms, K 2003. Paul Ricoeur. London: Routledge. (Routledge Critical Thinkers. Essential Guides for Literary Studies.)

Smend, R 1966. Nachkritische Schriftauslegung, in Busch, E (Hrsg), Parrhesia: Karl Barth zum achtigsten Geburtstag, 215-237. Zürich: EVZ Verlag.

Smend, R 1985. Die Kritik am Alten Testament, in Lange, D (Hrsg), Friedrich Schleiermacher 1768-1834: Theologe - Philosoph - Pädagoge, 106-128. Göttingen: Vandenhoeck \& Ruprecht.

Stegemann, W 1978. Der Denkweg Rudolf Bultmanns: Darstellung der Entwicklung und der Grundlagen seiner Theologie. Stuttgart: Kohlhammer.

Stiver, D R 2007. Felicity and fusion: Speach act theory and hermeneutical philosophy, in Vanhoozer, K \& Warner, M (eds), Transcending boundaries in philosophy and theology: Reason, meaning and experience, 145-156. Hampshire: Ashgate.

Sykes, S 1982. Barth and the power of the Word. Philadelphia, PA: Fortress.

Torrance, T F 1976. Space, time and resurrection. Grand Rapids, MI: Eerdmans.

Torrance, T F 1990. Karl Barth: Biblical and evangelic theologian. Edinburgh: T\&T Clark.

Troeltsch, E 1992. Über historische und dogmatische Methode in der Theologie, in Gesammelte Schriften, Band 2: Zur reliogösen Lage, Religionsphilosphie und Ethik, 729-753. 2. Nachdruck der 2. Auflage. Tübingen: Mohr.

Trowitzsch, M 1996. Nachkritische Schriftauslegung: Wiederaufnahme und Fortführung einer Fragestellung, in Trowitzsch, M (Hrsg), Karl Barths Schriftauslegung, 73-109. Tübingen: Mohr Siebeck.

Van Aarde, A G 1996. Historical Jesus research in perspective. (Original printed in Afrikaans). HTS 52(2\&3), 476-500.

Van Aarde, A G 2000. Understanding Jesus' healings. Scriptura 18, 1-19.

Van Aarde, A G 2001. Millennialism, eschatology, and apocalypticism. (Original printed in Afrikaans). HTS 57(3\&4), 1158-1178. 
Von Balthasar, H U 1971. The theology of Karl Barth, tr by J Drury. New York: Holt, Reinhart \& Winston.

Von Harnack, A [1999]. Das Wesen des Christentums, herausgegeben und kommentiert von T Rendtorff. Gütersloh: Gütersloher.

Von Rancke, L [1824] 1973. Geschichte der romanischen und germanischen Völker von 1492 bis 1535, in Iggers, G G \& Von Moltke, K (Hrsg), Introduction, in The theory and practice of history, xix-xx. New York: Bobbs-Merill.

Wallace, M I [1990] 1995. The second naiveté: Barth, Ricoeur, and the New Yale Theology. Macon, GA: Mercer University Press. (Studies in American Biblical Hermeneutics 6.)

Warner, M 2007. Transcending boundaries in philosophy and theology, in Vanhoozer, K \& Warner, M (eds), Transcending boundaries in philosophy and theology: Reason, meaning and experience, 15-30. Hampshire: Ashgate.

Weber, O [1963] 1967. Karl's Barth's Kirchliche Dogmatik: Ein einfuhrender Bericht. 6. Auflage. Neukirchen-Vluyn: Neukirchener Verlag.

Webster, J B 1981. Recent work on Barth since 1975. Themelios 7(3), 31-35.

Webster, J B 1994. Assured and patient and cheerful expectation: Barth on Christian hope as the church's task. Toronto Journal of Theology 10, 35-52.

Webster, J B 1995. Barth's ethics of reconciliation. Cambridge: Cambridge University Press.

Webster, J B 1998. Barth's moral theology: Human action in Barth's thought. Grand Rapids, MI: Eerdmans.

Webster, J B [2000] 2004. Karl Barth. 2nd ed. New York: Continuum.

Wellmer, A 1976. Communication and emancipation: Reflections on the linguistic turn of critical theory, in J O'Neill (ed), On critical theory, 231-263. London: Heinemann.

Zahrnt, H ([1966] 1967). Die Sache mit Gott: Die protestantische Theologie im 20. Jahrhundert. München: R Piper. 